\title{
PATTERN ANALYSIS OF MULTI-ENVIRONMENT TRIALS IN COMMON BEAN GENOTYPES
}

\section{ANÁLISE DE PADRÕES DE ENSAIOS MULTI-AMBIENTAIS EM FEIJÃO COMUM}

\author{
Agenor Martinho CORREA ${ }^{1}$; Manoel Carlos GONÇALVES ${ }^{2}$; Paulo Eduardo TEODORO \\ 1. Departamento de Fitotecnia, Universidade Estadual de Mato Grosso do Sul, Aquidauana, MS, Brasil; 2. Departamento de Estatística, \\ Universidade Federal da Grande Dourados, Dourados, MS, Brasil; 3. Departamento de Biologia Geral/Laboratório de Biometria, \\ Universidade Federal de Viçosa, Viçosa, MG, Brasil.
}

\begin{abstract}
The aim of this study was to use the patterns analysis technique to investigate the grain yield of 13 common bean genotypes evaluated in 12 environments in the State of Mato Grosso do Sul, under presence of genotype $\mathrm{x}$ environment interaction ( $\mathrm{G}$ x E). The trials were conducted between the years 2000-2006 at Universidade Estadual de Mato Grosso do Sul, Unit of Aquidauana, and at Faculdade de Ciências Agrárias da Universidade Federal da Grande Dourados. Have been identified nine groups of genotypes and environments. It were submitted the grain yield data to individual and joint variance analysis. Subsequently, it was performed the pattern analysis, which was made the cluster of genotypes and environments with similar patterns and its means grouping by Scott-Knott's test. The first two principal components of ordination analysis explained $56.6 \%$ of the total variation of $\mathrm{G} \times \mathrm{E}$ interaction data. Pattern analysis proved to be efficient in identifying groups of environments that discriminate similarly genotypes, genotypes with similar performance in all environments, and in the description of the genotypes stability patterns.
\end{abstract}

KEYWORDS: Phaseolus vulgaris L. Cluster analysis. Genotypes x environments interaction. Principal components analysis.

\section{INTRODUCTION}

In the common bean breeding programs, it is tested a large number of genotypes annually in different environments before its final recommendation and multiplication (CORRÊA et al., 2015). However, in most cases, these environments are distinct, and there is an interaction between the genotype and environment $(\mathrm{G} x$ E), which affects the gain with selection and makes necessary to estimate the magnitude and the nature of this interaction. These estimates allow assessing the real impact of selection and ensure high reliability in the genotype recommendation for a specific place or environment groups (ROSADO et al., 2012).

$\mathrm{G} \times \mathrm{E}$ can be defined as the differential effect of the environment on the genotypes or on the other hand, as the differential response of genotypes to environmental changes, manifesting itself in the form of gene expression (CHAVES, 2001). Thus, the simple analysis of the interaction $\mathrm{G} \times \mathrm{E}$ does not provide complete and accurate information about the behavior of each genotype in various environmental conditions. It is necessary to realize adaptability and phenotypic stability analysis, in which the identification of genotypes with predictable behavior is possible, that are responsive to environmental variations in specific or broad conditions (CRUZ et al., 2014).

Beyond traditional statistical methods used to evaluate, study and interpret the $\mathrm{G} \times \mathrm{E}$ is realized on the analysis of variance from the interaction
(WRICKE, 1965); in the simple linear regression (EBERTHART; RUSSELL, 1966) and linear bissegmented regression (CRUZ et al., 1989); that require no statistical assumption, called nonparametric (LIN; $\quad$ BINNS, 1988; ANNICCHIARICO, 1992). Recently, three new methodologies that employ multivariate analysis and which help to analyze data from multienvironment trials, enabling a better understanding of $\mathrm{G} \times \mathrm{E}$, should be highlighted: Additive Main Effects Analysis and Multiplicative Interaction Model (GAUCH; ZOBEL, 1988), Pattern Analysis that has been developed and updated by Watson et al. (1966), GGE Biplot Analysis (genotype main effect + genotype environment interaction) which was developed by Yan (2001), Artificial Neural Networks (NASCIMENTO et al., 2013; TEODORO et al., 2015a) and Bayesian perspective (NASCIMENTO et al., 2011; TEODORO et al., 2015b; BARROSO et al., 2016).

Pattern analysis has been used in many multi-environment experiments demonstrating high efficiency (ABDALLA et al., 1996; REEDEN et al., 2000; LILLEMO et al., 2004, KAYA et al, 2006; ZHANG et al., 2006). According to Delacy et al. (2000), data of genotype x environment obtained by multi-environment trials conducted over a wide range of environments, can be investigated by Pattern Analysis to identify genotypes with similar responses in all environments and environments that discriminate among similarly genotypes. 
The technique it is based on the set and complementary use of classification and ordination techniques (cluster analysis and principal component analysis) to study different aspects of the genotypes response patterns. Cluster analysis summarizes the complexity of the data retaining most of the information by the cluster of varieties with similar performance in, relatively, few environmental groups that discriminate similarly cultivar performance (DELACY et al., 2000).

Although it is disseminated worldwide, has not yet found any Brazilian studies that employed the pattern analysis. The aim of this study was to use the patterns analysis technique to investigate the grain yield of 13 common bean genotypes evaluated in 12 environments in the State of Mato Grosso do Sul, under presence of genotype $\mathrm{x}$ environment interaction $(\mathrm{G} \times \mathrm{E})$.

\section{MATERIAL AND METHODS}

Have been conducted the trials in 12 different environments, from 2000 to 2006, each environment constituting the combination of a place in a growing season and a crop year (Table 1). In Dourados, MS, the trials were performed at the Experimental Area of Universidade Federal da Grande Dourados $\left(22^{\circ} 12^{\prime} \mathrm{S}\right.$ and $54^{\circ} 48^{\prime} \mathrm{W}$, and altitude of $452 \mathrm{~m}$ ). The soil where was carried out the trial is classified as Oxisol Distroferric, clayey and flat topography. In Aquidauana, MS, tests were carried out at Universidade Estadual de Mato

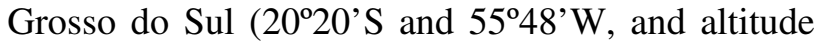
of $174 \mathrm{~m}$ ). The soil where was conducted the trials in Aquidauana is classified as Ultisol Dystroferric physically deep, moderately drained and sandy texture.

Table 1. Characterization of trial environments.

\begin{tabular}{|c|c|c|c|c|c|c|c|}
\hline Environment & Code & Place & Climate & Season & Crop & $\begin{array}{c}\text { Average } \\
\text { Temperature }\left({ }^{\circ} \mathrm{C}\right)\end{array}$ & $\begin{array}{l}\text { Accumulated } \\
\text { rainfall }(\mathrm{mm})\end{array}$ \\
\hline EA & 1 & Dourados & Cwa & Rainy & $2000 / 2001$ & 27,1 & 381 \\
\hline EB & 2 & Dourados & Cwa & Drought & $2000 / 2001$ & 22,7 & 185 \\
\hline $\mathrm{EC}$ & 3 & Aquidauana & Aw & Drought & $2000 / 2001$ & 24,7 & 170 \\
\hline ED & 4 & Dourados & Cwa & Rainy & $2001 / 2002$ & 27,4 & 412 \\
\hline $\mathrm{EE}$ & 5 & Dourados & Cwa & Drought & $2001 / 2002$ & 22,4 & 195 \\
\hline $\mathrm{EF}$ & 6 & Aquidauana & Aw & Drought & $2001 / 2002$ & 24,9 & 201 \\
\hline EG & 7 & Aquidauana & Aw & Drought & $2002 / 2003$ & 23,8 & 181 \\
\hline $\mathrm{EH}$ & 8 & Aquidauana & Aw & Drought & $2003 / 2004$ & 23,6 & 190 \\
\hline EI & 9 & Aquidauana & Aw & Drought & $2004 / 2005$ & 22,9 & 176 \\
\hline EJ & 10 & Dourados & Cwa & Rainy & $2005 / 2006$ & 27,6 & 356 \\
\hline EK & 11 & Dourados & Cwa & Drought & $2005 / 2006$ & 22,1 & 203 \\
\hline $\mathrm{EL}$ & 12 & Aquidauana & Aw & Drought & $2005 / 2006$ & 24,5 & 193 \\
\hline
\end{tabular}

The trials have been deployed only in drought season, with the date of sowing ranging from one year to another, prevailing, however, dates between 10 to 20 April. The germplasm used in the trials except the IAC-Carioca Eté, came from the
Germplasm Bank of EMBRAPA, Centro Nacional de Pesquisa de Arroz e Feijão (CNPAF - GoiâniaGO) and consisted of cultivars and advanced lines discriminated in Table 2.

Table 2. Description of genotypes used in the trials.

\begin{tabular}{|c|c|c|c|}
\hline Genotype & Classification & Commercial Group & Growth Habit \\
\hline Rudá & Cultivar & Carioca & Tipe II \\
\hline Aporé & Cultivar & Carioca & Tipe III \\
\hline Xamego & Cultivar & Black & Tipe II \\
\hline Pérola & Cultivar & Carioca & Tipe III \\
\hline Ouro Negro & Cultivar & Black & Tipe III \\
\hline Diamante Negro & Cultivar & Black & Tipe II \\
\hline IAPAR 14 & Cultivar & Carioca & Tipe III \\
\hline EMGOPA 201-Ouro & Cultivar & Various & Tipe II \\
\hline IAC-Carioca Eté & Cultivar & Black & Tipe III \\
\hline CNF 7135 Bambuí & Lineage & Various & Tipe II \\
\hline CNF4999-RioTibagi & Lineage & Black & Tipe II \\
\hline CNF4129A54 & Lineage & Various & Tipe II \\
\hline CNFv8025 & Lineage & Black & Tipe II \\
\hline
\end{tabular}


The experimental design consisted of randomized blocks with three replications. The experimental unit consisted of two rows of plants with $1.50 \mathrm{~m}$ long each, spaced $0.50 \mathrm{~m}$. The sowing furrows were mechanically opened and fertilization carried out according to the soil analysis data. The employed seeding rate was 15 seeds per meter, and was manually performed the nitrogen topdressing in the physiological stage V4, distributing in continuous thread next to the rows of plants $40 \mathrm{~kg}$ $\mathrm{ha}^{-1} \mathrm{~N}$, employing as source urea or ammonium sulfate. When using urea it was incorporated to the soil surface so that nitrogen losses by volatilization were minimized.

The trials were kept free of the presence of invasive plants through hand weeding carried out between 15-30 days after emergence and the control of pests and diseases was conducted according to Zimmermann et al, (1996). Both in trials in Aquidauana as in Dourados, it was carried out the irrigation using supplementary set of conventional sprinkler irrigation when needed. The harvest consisted of manual uprooting of the plants when it were fully dried and grain moisture content around $15 \%$, which characterizes the end of stage R9. The uprooted plants were stacked in the field and threshed with flexible sticks.

We evaluated grain yield (YIE) considering the production of the harvested area in the plot transformed into $\mathrm{kg} \mathrm{ha}^{-1}$ of grains. It was adjusted the grain yield for moisture $13 \%$ in grains. Initially, it was performed individual variance analysis for each environment, considering environmental and $G$ $x \mathrm{E}$ interaction effects as random and the genotype effects as fixed, in order to determine the relative magnitude of the sums of squares attributable to the genotype, environment and $\mathrm{G} \times \mathrm{E}$ interaction effects. The scheme used in the individual variance analysis was the randomized blocks, which adopted statistical model was (CRUZ et al., 2014): $\mathrm{Y}_{\mathrm{ij}}=\mu+\mathrm{g}_{\mathrm{i}}+\mathrm{b}_{\mathrm{j}}+\varepsilon_{\mathrm{ij}}$, wherein $\mathrm{Y}_{\mathrm{ij}}$ is the value observed for the $\mathrm{i}$-th genotype on $\mathrm{j}$-th block; $\mu$ is the overall mean of the trial; $g_{i}$ is the effect of the genotype $\mathrm{i} ; \mathrm{b}_{\mathrm{j}}$ is the effect of the block $\mathrm{j} ; \varepsilon_{\mathrm{ij}}$ : is the random error associated to observation $Y_{\mathrm{ij}}$.

Subsequently, it was found that the ratio between the largest and smallest mean square of the environments was less than seven, then being performed the analysis of variance, following the statistical model (CRUZ et al., 2014): $\mathrm{Y}_{\mathrm{ijk}}=\mu+\mathrm{g}_{\mathrm{i}}+(\mathrm{b} / \mathrm{a})_{\mathrm{jk}}+\mathrm{a}_{\mathrm{j}}+\mathrm{ga}_{\mathrm{ij}}+\varepsilon_{\mathrm{ijk}}$, wherein: $\mathrm{Y}_{\mathrm{ijk}}$ is the observation in k-th block of $\mathrm{i}$-th genotyoe on $j$-th environment; $\mu$ is the overall mean of the trial; $g_{i}$ is the effect of $i$-th genotype; $(b / a)_{j k}$ is the effect of block k within $j$-th environment; $a_{j}$ id the effect of j-environment; $\mathrm{ga}_{\mathrm{ij}}$ is the effect of $\mathrm{i}$ genotype in j-environment; $\varepsilon_{\mathrm{ijk}}$ is the random error associated to observation $Y_{\mathrm{ijk}}$.

Before proceeding the cluster analysis, the matrix of $\mathrm{G} x \mathrm{E}$ interaction, containing the YIE trait data, it was transformed within environments, removing the main effects of environments with great significance and dividing the remaining effects within environment by the standard deviation (DELACY, 2000). From transformed average matrices was computed a dissimilarity matrix (square matrix of Euclidean distance) for each genotype and environment. Standardization was made according to the expression: $Y^{\prime}{ }^{\prime}{ }^{\prime}{ }^{\prime}=\left(Y_{i j}-\right.$ $\left.\mathrm{Y}_{\mathrm{j}}\right) / \mathrm{Sd}$, wherein $\mathrm{Y}^{\prime}{ }^{\prime}{ }^{\prime}{ }^{\prime}$ ' is the standardized averages of the entries in environments $j ; Y_{i j}$ is the observed average of the entries in environments $j ; Y_{j}$ is the average of all the entries in the environment $\mathrm{j} ; \mathrm{Sd}$ is the phenotypic standard deviation in the environment $\mathrm{j}$.

The standardization of environments leads to the grouping of those environments that are more similar in the way they classify genotypes (FOX; ROSIELLE, 1992) and, genotypes clusters formed with this standardization, contain genotypes which show similar performance levels. It was carried out the classification of cultivars and environments using an agglomerative hierarchical cluster method using the square of the Euclidean distance as a measure of dissimilarity. Ward's method, that uses the sums of squares increments was the method used in the cluster strategy for construction of dendograms. In this method, are joined the groups to minimize new groups of sum of squares (CRUZ et al., 2014).

It was determined the classification effectiveness by evaluation of dividing the sum of squares among sources. It were truncated cultivars classifications for the sake of brevity, when $50 \%$ of the sum of squares of $\mathrm{G} \times \mathrm{E}$ interaction was retained in the reduced matrix (BYTH et al., 1976). It were built dendograms based on the level of fusion to examine similarities in performance standards among genotypes (in response to environments) and environments (in discrimination for genotypes).

It was built a biplot using the singular value decomposition procedure (GABRIEL, 1971) and the averages of the genotypes clustered by Scott-Knott's method at $5 \%$ probability. Statistical analyzes were 
Pattern analysis...

performed by the software GENES (CRUZ, 2013) and CROPSTAR (IRRI, 2007).

\section{RESULTS AND DISCUSSION}

In the joint analysis (Table 3), all effects were significant $(\mathrm{P} \leq 0.01)$, which indicates the
CORREA, A. M. et al.

contrast among the environments and the occurrence of differential response of the genotypes to environmental effects. The environment was the source of variation that most contributed to the YIE total sum of square, indicating that the edaphoclimatic features of each environment significantly interferes in this trait.

Table 3. Summary of joint analysis of variance for grain yield, evaluated in 13 genotypes of common bean in 12 environments in Mato Grosso do Sul.

\begin{tabular}{lccc}
\hline Variation Sources & DF & MS & \% Total SS \\
\hline Environment (E) & 11 & $6,365,104.37$ & 65,34 \\
Genotype (G) & 12 & $2,724,265.05$ & 27,97 \\
G X E & 132 & $606,890.43$ & 6,23 \\
Residue & 288 & $44,774.84$ & 0,46 \\
Total & 467 & --- & 100.00 \\
CV $(\%)$ & 11,19 & --- & --- \\
\hline
\end{tabular}

* significant at $1 \%$ probability the F-test; DF: degrees of freedom; MS: mean square; SS: sum of square; MS: mean square; CV: coefficient of variation.

The pattern analysis allowed establishing that the reduction in size of the matrix data was $48.08 \%$ and the percentage of the total sum of squares of $\mathrm{G} \times \mathrm{E}$ interaction retained in the reduced matrix was $84.46 \%$, well above, therefore, of the $50 \%$ set as a classification criterion (Table 3). The application of truncation levels where $50 \%$ or more of the sums of squares of $\mathrm{G} \times \mathrm{E}$ interaction were maintained led to the formation of nine environment groups, whose results of cluster analysis are shown in Figure 1 and Table 4. The knowledge of the environments ordering and classification is an important prerequisite for the effective conduction of trials in representative environments. This procedure can reduce the number of trials, minimizing costs and still allowing the establishment of specific patterns for characterization and/or adaptation of genotypes.

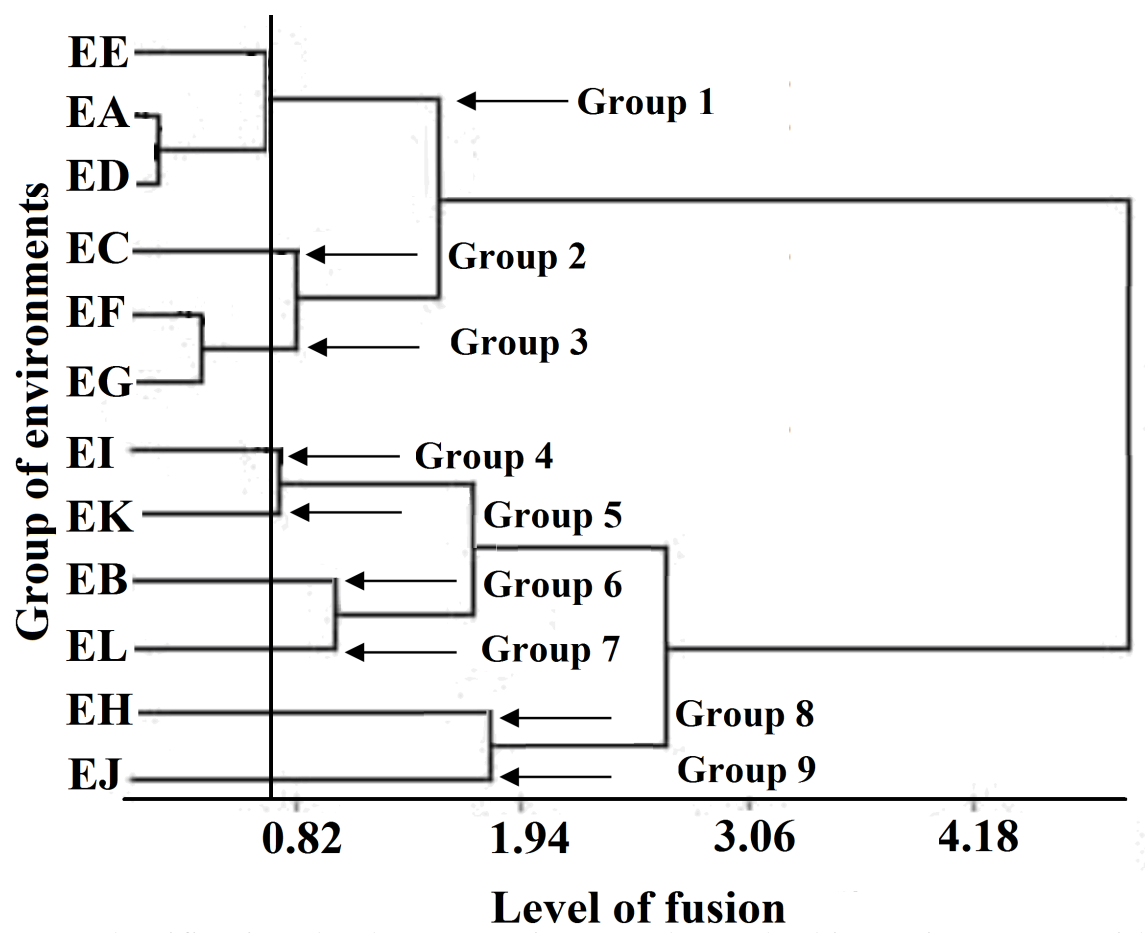

Figure 1. Environment classification dendrogram using Ward's method in environments with standardized means. 
Table 4. Members and means of groups of environments established for grain yield of 13 common bean genotypes.

\begin{tabular}{ccc}
\hline Group & Environments & Grain yield $\left(\mathrm{kg} \mathrm{ha}^{-1}\right)$ \\
\hline & EA & $1,672.2 \mathrm{c}^{(1)}$ \\
& ED & $1,833.6 \mathrm{c}$ \\
2 & EE & $1,827.9 \mathrm{c}$ \\
3 & EC & $2,173.5 \mathrm{~b}$ \\
4 & EF & $2,341.8 \mathrm{a}$ \\
5 & EG & $2,070.1 \mathrm{~b}$ \\
6 & EI & $1,703.2 \mathrm{c}$ \\
7 & EK & $1,561.9 \mathrm{c}$ \\
8 & EB & $1,558.1 \mathrm{c}$ \\
9 & EL & $2,520.0 \mathrm{a}$ \\
\hline
\end{tabular}

Means followed by the same letter in the same column belong to the same group by Scott-Knott's test at 5\% probability.

The environments pattern analysis identified the environments, EA, ED and EE (group 1) and the environments EF and EG (group 14) as environments that discriminated similarly the genotypes. The others environments discriminated the genotypes in a specific way, reason why constituted isolated groups (Figure 1). The environments, EA, ED and EE refer to the locality of Dourados, the first two to rainy season and the last to drought season. The environments $\mathrm{EF}$ and EG, which also showed similarity in the discrimination of genotypes, refer to the growing in the drought season, in the agricultural years
2001/2002 and 2002/2003, respectively, in Aquidauana. The proximity of these environments in the dendrogram, whose joint levels put it in the same group, indicates macro and microenvironmental similarity to the common bean cultivation.

The result of the pattern analysis, classificatory for genotypes established nine groups, being only three with more than one genotype. The other genotypes with specific performances remained constituting isolated groups. These results are shown in Figure 2 and Table 5.

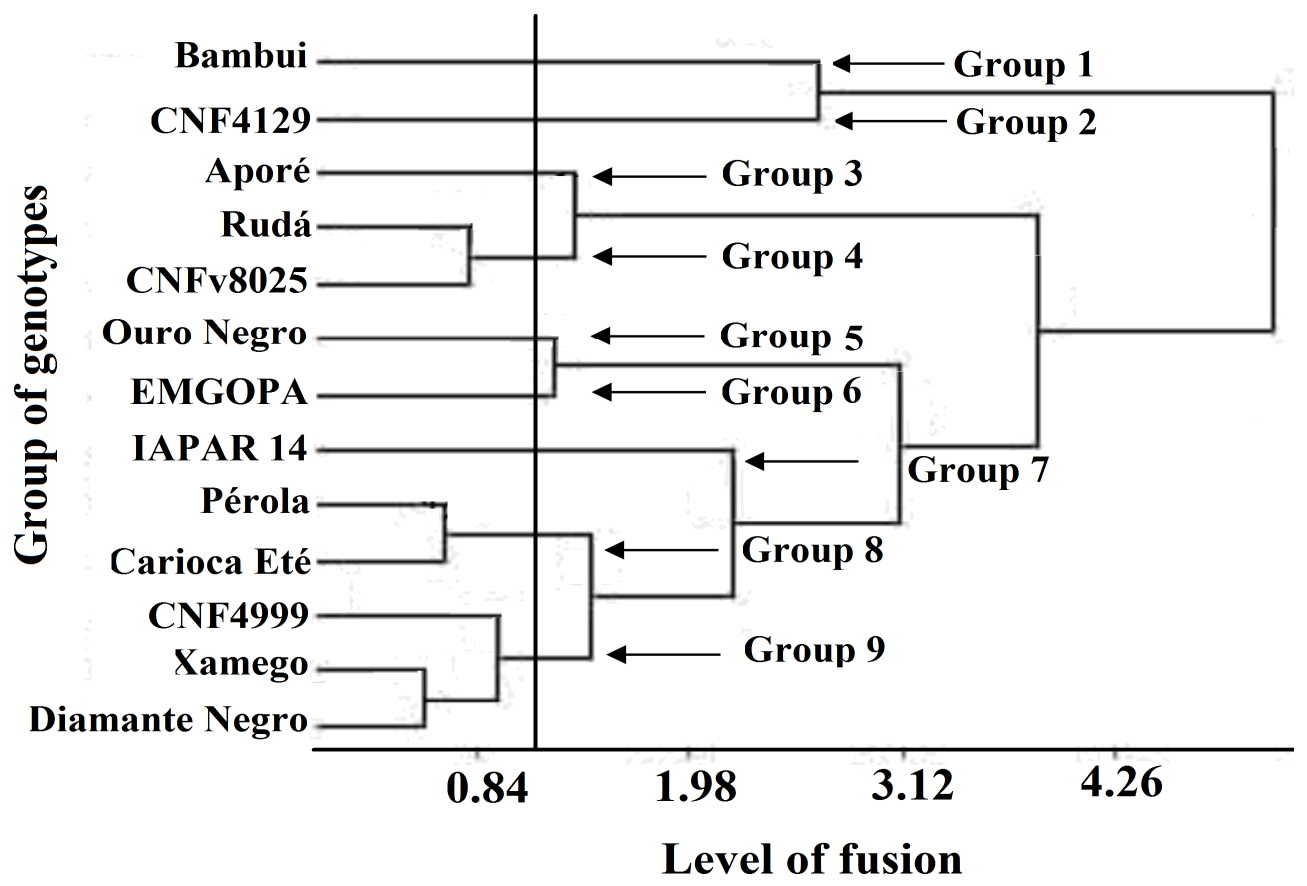

Figure 2. Genotype classification dendrogram using Ward's method in environments with standardized means. 
Table 5. Members and means of groups of genotypes established for grain yield evaluated in 12 environments in Mato Grosso do Sul.

\begin{tabular}{lcc}
\hline Group & Genotype & Grain yield $\left(\mathrm{kg} \mathrm{ha}^{-1}\right)$ \\
\hline 1 & Bambui & $1,629.1 \mathrm{c}^{(1)}$ \\
2 & CNF4129 & $1,763.2 \mathrm{c}$ \\
3 & Aporé & $2,307.8 \mathrm{a}$ \\
4 & Rudá & $2,178.0 \mathrm{a}$ \\
5 & CNFv 8025 & $1,964.7 \mathrm{~b}$ \\
6 & Ouro Negro & $1,963.6 \mathrm{~b}$ \\
7 & EMGOPA & $2,305.6 \mathrm{a}$ \\
8 & IAPAR 14 & $1,867.0 \mathrm{c}$ \\
& Pérola & $1,713.5 \mathrm{~d}$ \\
9 & Carioca Eté & $1,728.8 \mathrm{c}$ \\
& CNF4999 & $1,763.2 \mathrm{c}$ \\
& Xamego & $2,037.2 \mathrm{~b}$ \\
\hline
\end{tabular}

Means followed by the same letter in the same column belong to the same group by Scott-Knott's test at 5\% probability.

Group 9 gathered genotypes with similar performance in all environments belonging to the same commercial group. The cultivars Xamego, Diamante Negro and the line CNF 4999-Rio Tibagi have grain with black coloring, being the first two grown in various producer regions. It can be observed however, that the mean of the cultivar Xamego, with the greater yield $\left(2,037.2 \mathrm{~kg} \mathrm{ha}^{-1}\right)$, differed statistically from the means of the two other, which not differ from each other (Table 5).

The group 8 also gathered genotypes with similar response in all environments belonging to the same commercial group. The cultivars Pérola and Carioca Eté are the carioca group and are widely grown in the production regions due to the good performance shown, however, in this study, both presented only regular performance within the evaluated set. Group 4 gathered the line CNFv 8025, black beans, and the cultivar Rudá, carioca beans, whose performance also differed by Scott-Knott's test (Table 5). Based on the presented results it can be inferred that the pattern analysis was efficient to come together into one group genotypes with simillar commercial features, which may be due to the existence of a narrow genetic base between it.

The first two principal components of ordination analysis explained $56.6 \%$ of the total sum of squares of $\mathrm{G} \times \mathrm{E}$ interaction, (Figure 3), significant percentage considering the quantitative nature of this trait. In biplot genotypes are represented by derivatives points of its scores for the first two principal components (IPC1 and IPC2) and the environments as vectors of the original biplots of its points.

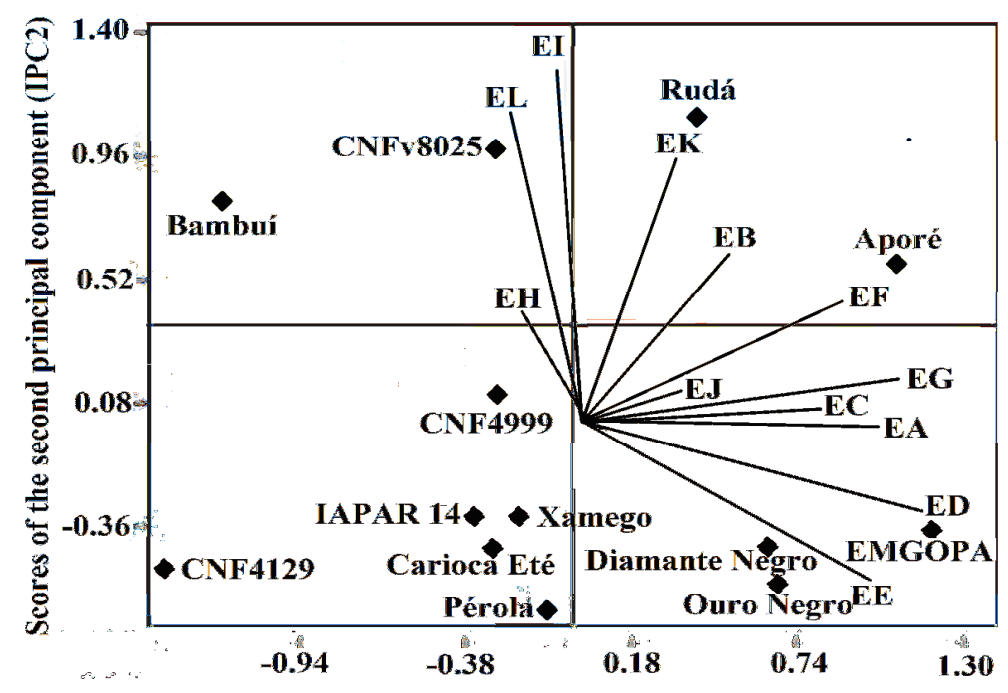

Scores of the first principal component (IPC1)

Figure 3. Biplot for first and second principal components (IPC1 x IPC2) obtained from ordination of environmental standardized data. The environments are indicated as vectors of the original points and genotypes denoted by points. 
Analysis of environments groups allowed to identify the groups EI, EK and EL as the most unstable. The first two make up the group of the lowest means for YIE, while the latter comprises the group of the largest mean. The groups EH, EB and $\mathrm{EF}$ had intermediate instability. Is possible to identify in the biplot specific interaction among environments and genotypes, like ED and EMGOPA; EF and Aporé; EK, Rudá, EL and CNFv8025.

\section{CONCLUSIONS}

Pattern analysis proved to be efficient in identifying groups of environments that discriminate similarly genotypes, genotypes with similar performance in all environments, and in the description of the genotypes stability patterns.

It is possible to identify in the biplot by pattern analysis the genotypes EMGOPA, Aporé and Ruda as the most stable productivity, being recommended for cultivation in Mato Grosso do Sul.

RESUMO: O objetivo deste trabalho foi utilizar a técnica da análise de padrões para investigar a produtividade de grãos de 13 genótipos de feijoeiro comum, avaliados em 12 ambientes no Estado do Mato Grosso do Sul, sob presença de interação genótipos x ambientes (G x E). Os experimentos foram conduzidos entre os anos de 2000 a 2006 nas áreas experimentais da Universidade Estadual de Mato Grosso do Sul, unidade de Aquidauana, e da Faculdade de Ciências Agrárias da Universidade Federal da Grande Dourados. Nove grupos de genótipos e de ambientes foram identificados. Os dados de produtividade de grãos foram submetidos a análises de variância individual e conjunta. Posteriormente, realizada a análise de padrões, onde foi feito o agrupamento de genótipos e ambientes com padrões similares e suas médias agrupadas pelo teste de Scott-knott. Os dois primeiros componentes principais da análise de ordenação explicaram $56,6 \%$ da variação total dos dados da interação genótipos x ambientes. A análise de padrões mostrou-se eficiente na identificação de grupos de ambientes que discriminaram de forma semelhante os genótipos, de genótipos com desempenho semelhante em todos os ambientes, e na descrição dos padrões de estabilidade dos genótipos.

PALAVRAS CHAVE: Phaseolus vulgaris L. Análise de agrupamento. Interação genótipos x ambientes. Análise de componentes principais.

\section{REFERENCES}

ABDALLA, 0. S.; CROSSA, J.; AUTRIQUE, E.; DELACY, I. H. Relationships among international testing sites of spring durum wheat. Crop. Science, Madson, v. 36, p. 33-40, 1996.

ANNICCHIARICO, P. Cultivar adaptation and recommendation from alfafa trials in Northen Italy. Journal of Genetics and Plant Breeding, New Delhi, v, 46, p. 269-278, 1992.

BARROSO, L. M. A.; TEODORO, P. E.; NASCIMENTO, M.; TORRES, F. E.; SANTOS, A.; CORRÊA, A. M.; SAGRILO, E. CORRÊA, C. C. G.; SILVA, F. A.; CECCON, G. Bayesian approach increases accuracy when selecting cowpea genotypes with high adaptability and phenotypic stability. Genetics and Molecular Research, Ribeirão Preto, v. 15, n. 1, p. 1-11, 2016. http://dx.doi.org/10.4238/gmr.15017625

BYTH, D.E.; EISEMANN, R.I.; DELACY, I.H. Two-way pattern analysis of a large data set to evaluate genotypic adaptation. Heredity, Oxford, v. 37, p. 215-230, 1976. http://dx.doi.org/10.1038/hdy.1976.84

CHAVES, L. J. Interação de genótipos com ambientes. In: NASS, L. L.; VALOIS, A. C. C.; MELO, I. S.; VALADARS-INGLIS, M. C. C. Recursos genéticos e melhoramento-Planta. Rondonópolis: Fundação MT, 2001. p. 673-713.

CORREA, A. M.; LIMA, A. R. S.; BRAGA, D. C.; CECCON, G.; TEODORO, P. E.; SILVA JUNIOR, A. C.; SILVA, F. A. Agronomic Performance and Genetic Variability among Common Bean Genotypes in Savanna/Pantanal Ecotone. Journal of Agronomy (Print), New York, v. 14, p. 175-179, 2015.

CRUZ, C. D. GENES - a software package for analysis in experimental statistics and quantitative genetics. Acta Scientiarum Agronomy, Maringá, v. 35, p. 271-276, 2013. 
CRUZ, C. D.; REGAZZI, A. J.; CARNEIRO, P. C. S. Modelos biométricos aplicados ao melhoramento genético. 5. ed. Viçosa: UFV, 2014. 780p.

CRUZ, C. D.; TORRES, R. A. de.; VENCOVSKY, R. An alternative approach to be stability analysis proposed by Silva e Barreto. Revista Brasileira de Genética, Ribeirão Preto, v. 12, p. 567-580, 1989.

DELACY, I. H.; REDDEN, D. G.; BULTLER, T. Analysis of line x environment interactions for yield in navy beans. 3. Pattern analysis of environments over years. Australian Journal of Biological Sciences, Melbourne, v. 51, p. 619-628, 2000.

EBERHART, S. A.; RUSSELL, W. A. Stability parameters for comparing varieties. Crop Science, Madson, v. 6, p. 36-40, 1966.

FOX, P. N.; ROSIELLE, A. A. Reducing the influence of environmental main-effects on pattern analysis of plant-breeding environments. Euphytica, Dordredit, v. 31, p. 645-656, 1992.

GABRIEL, K. R. The biplot-graphical display of matrices with applications to principal components analysis.

Biometrika, Oxford. v. 58, p. 453-467, 1971. http://dx.doi.org/10.1093/biomet/58.3.453

GAUCH, H. C.; ZOBEL, R. W. Predictive and posdictive success of statistical analysis of yields trials. Theoretical and Applied Genetics, Berlin, v. 35, n. 3, p. 905-912, 1988.

INTERNATIONAL RICE RESEARCH INSTITUTE (IRRI). CROPSTAT v. 7.0. Tutorial Manual. Fillipines: Crop Research Informatic Laboratory, International Rice Research Institute, 2007. 332p.

KAYA, Y.; AKCURA, M.; RAMAZAN, A.; SEYFI, T. Pattern analysis of multi-environment trials in bread wheat. Communications in Biometry and Crop Science, Poland, v. 1, n. 2, p. 63-71, 2006.

LILLEMO, M.; TRETHOWAN, M. G. R. M.; HERNANDEZ, E.; RAJARAM, S. Associations among international CIMMYT bread wheat yield testing locations in high rainfail areas and their implications for wheat-breeding. Crop Science, Madson, v. 44, p. 1163-1169, 2004.

LINN, C. S.; BINNS, M. R. A. A superiority measure of cultivar performance for cultivar x location data. Canadian Journal of Plant Science, Ottawa, v. 68, p. 193-198. 1988. http://dx.doi.org/10.4141/cjps88-018

NASCIMENTO, M.; SILVA, F. F.; SÁFADI, T.; NASCIMENTO, A. C. M. C.; FERREIRA, R. P.; CRUZ, C. D. Abordagem bayesiana para avaliação da adaptabilidade e estabilidade de genótipos de alfafa. Pesquisa

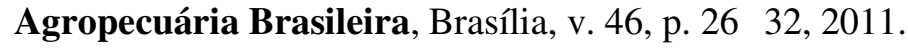

NASCIMENTO, M.; PETERNELLI, L.A.; CRUZ, C.D.; NASCIMENTO, A.C.C.; FERREIRA, R. de P.; BHERING, L.L.; SALGADO, C.C. Artificial neural networks for adaptability and stability evaluation in alfalfa genotypes. Crop Breeding and Applied Biotechnology, Viçosa, v. 13, p. 152? 156, 2013.

REDEEN, R. J.; DELACY, I. H.; BURLER, D. G.; USHER, T. Analysis of line by environment interactions for yield navy beans. 2. Pattern analysis of cultivars and environment within years. Australian Journal of Biological Sciences, Melbourne, v. 51, p. 607-617, 2000.

ROSADO, A. M.; ROSADO, T. B.; ALVES, A. A.; LAVIOLA, B. G.; BHERING, L. L. Seleção simultânea de clones de eucalipto de acordo com produtividade, estabilidade e adaptabilidade. Pesquisa Agropecuária Brasileira, Brasília, v. 47, n. 7, p. 964-971, 2012. http://dx.doi.org/10.1590/S0100-204X2012000700013

SILVA J. G. C. Análise da adaptabilidade por regressão segmentada com estimação da junção dos segmentos. Pesquisa Agropecuária Brasileira, Brasília, v. 33, n. 7, p. 1013-1029, 1998. 
TEODORO, P. E.; BARROSO, L. M. A.; NASCIMENTO, M.; TORRES, F. E.; SAGRILO, E.; SANTOS, A.; RIBEIRO, L. P. Redes neurais artificiais para identificar genótipos de feijão-caupi semiprostrado com alta adaptabilidade e estabilidade fenotípica. Pesquisa Agropecuária Brasileira, Brasília, v. 50, p. 1054-1060, 2015a. http://dx.doi.org/10.1590/S0100-204X2015001100008

TEODORO, P. E.; NASCIMENTO, M.; TORRES, F. E.; BARROSO, L. M. A.; SAGRILO, E. Perspectiva bayesiana na seleção de genótipos de feijão-caupi em ensaios de valor de cultivo e uso. Pesquisa Agropecuária Brasileira, Brasília, v. 50, p. 878-885, 2015b. http://dx.doi.org/10.1590/S0100-204X2015001000003

WATSON, S. H.; DELACY, I. H.; PODLICH, D.W.; BASFORD, K. E. GEBEI. An analysis using agglomerative hierarchical classificatory and SVD ordination procedures for genotype $x$ environment data, Queensland, 1996. 57p.

WRICKE, G. ZUR. Berechimung der okovalenz. Bei Sommerweizen und Hafer. Zeistschrift fur Pflanzenziichtung, Berlin, v. 52, p. 127-138, 1965.

YAN, W. GGEbiplot-a Windows application for graphical analysis ofmultienvironment trial data and other types of tw0-way data. Agronomy Journal, Madison, v. 93, p. 1111-1118, 2001.

http://dx.doi.org/10.2134/agronj2001.9351111x

ZHANG, Y.; HE, Z.; ZHANG, A.; GINKEL van, M.; YE, G. Pattern analysis on grain yield performance of Chinese and CIMMYT spring wheat cultivars sown in China an CIMMYT. Euphytica, Dordredit, v. 147, p. 409420, 2006.

ZIMMERMANN, M. J. O.; CARNEIRO, J. E. S.; DEL PELOSO, M. J.; COSTA, J. G.; RAVA, C. A.; SARTORATO, A.; PEREIRA, P. A. A. F. Melhoramento genético e cultivares. In: ARAUJO, R. S.; RAVA, C. A.; STONE, L. F.; SIMMERMANN, M. J. O (eds). A cultura do feijoeiro-comum no Brasil. Piracicaba: Associação Brasileira para Pesquisa da Potassa e do Fosfato, 1996, p. 223-262. 